\title{
Dopaminergic Stimulation of Oxytocin Concentrations in the Plasma of Male and Female Monkeys by Apomorphine and a $\mathrm{D}_{2}$ Receptor Agonist*
}

\author{
JUDY L. CAMERON, STEVEN M. POMERANTZ, LISA M. LAYDEN, \\ AND JANET A. AMICO† \\ Departments of Behavioral Neuroscience (J.L.C., L.M.L.), Medicine (J.A.A.), Physiology (J.L.C., S.M.P.), \\ and Psychiatry (J.L.C.), University of Pittsburgh School of Medicine, and Oakland Department of Veterans \\ Affairs (J.A.A.), Pittshurgh, Pennsylvania 15261
}

\begin{abstract}
Administration of the dopamine receptor agonist apomorphine causes a dose-dependent increase in plasma oxytocin concentrations and dose-specific behavioral changes in rodents. To investigate whether dopamine receptor agonists will elicit similar neuroendocrine and behavioral effects in primates, we administered graded doses of apomorphine and the respective dopamine $D_{1}$ and $D_{2}$ receptor agonists, $C Y$ 208-243 and LY 163502, to monkeys and monitored plasma concentrations of oxytocin and behavior. Five female rhesus, two male rhesus, and two male cynomolgus monkeys had chronic indwelling venous catheters implanted and were maintained on standard jacket/tether/ swivel systems to allow remote blood sample collection. During experiments, blood samples were collected 10 and $5 \mathrm{~min}$ before drug injection and at 2- to 120-min intervals after each injection. Apomorphine (50$400 \mu \mathrm{g} / \mathrm{kg})$ and LY $163502(10-100 \mu \mathrm{g} / \mathrm{kg})$ elicited dose-dependent
\end{abstract}

stimulations of oxytocin secretion. CY $208-243(100-400 \mu \mathrm{g} / \mathrm{kg})$ did not significantly affect oxytocin secretion. Low doses of apomorphine $(50-100 \mu \mathrm{g} / \mathrm{kg})$ and LY $163502(10-25 \mu \mathrm{g} / \mathrm{kg})$ elicited yawning, and high doses of apomorphine $(200400 \mu \mathrm{g} / \mathrm{kg})$ and LY $163502(50-100$ $\mu \mathrm{g} / \mathrm{kg}$ ) elicited stereotypic behaviors. No behavioral effects of CY 208$243(100-400 \mu \mathrm{g} / \mathrm{kg})$ were observed. The magnitude of the oxytocin secretory responses varied among animals, but was similar in male and female monkeys. In summary, apomorphine and LY 163502 both elicited dose-related stimulation of oxytocin secretion coupled with dose-specific behavioral changes in male and female monkeys, while no effects of CY 208-243 on these parameters were observed. We conclude that dopamine receptor agonists, and in particular $\mathrm{D}_{2}$ agonists, may be useful tools for studies exploring the physiological and behavioral actions of oxytocin in primates. ( $J$ Clin Endocrinol Metab 75: $855-860,1992)$
$\mathrm{O}^{2}$ XYTOCIN is a nonapeptide that is synthesized in magnocellular and parvocellular neurons of the paraventricular and supraoptic nuclei of the hypothalamus and is released from the mammalian neurohypophysis in response to appropriate physiological stimuli. The release of oxytocin into the peripheral circulation has been associated with a variety of reproductive-related behaviors, including milk ejection (1), labor and delivery (2), ovulation (3), and coitus (4). Moreover, the administration of oxytocin into the central nervous system of rodents elicits specific reproductive-related behaviors, such as the induction of maternal behavior (5) and sexual behavior in male and female rats $(6,7)$.

Peripheral administration of the dopamine receptor agonist apomorphine, which binds to dopamine $D_{1}$ and $D_{2}$ receptors $(8,9)$, causes penile erection and yawning in male

Received September 19, 1991.

Address all correspondence and requests for reprints to: Janet $\mathrm{A}$. Amico, M.D., Division of Endocrinology and Metabolism, E-1140 Biomedical Science Tower, University of Pittsburgh School of Medicine, Pittsburgh, Pennsylvania 15261

* This work was supported by funds from the Department of Veterans Affairs (to J.A.A.) and NIH Grants HD-25929 (to J.L.C.), HD-25145 (to S.M.P.), and HD-08610 (to J.A.A., J.L.C., and S.M.P.). Presented in part at the 20th Annual Meeting of the Society for Neuroscience, November 1990 , St. Louis, MO, and the New York Academy of Sciences Conference on Oxytocin in Maternal, Sexual, and Social Behaviors, May 1991, Arlington, VA.

† Clinical Investigator in the Career Development Program of the Department of Veterans Affairs. rats in conjunction with increases in plasma oxytocin concentrations (10). Moreover, intracerebroventricular (icv) injection of oxytocin into rats elicits penile erection and yawning in male rats (11). Penile erection and yawning induced by administration of either icv oxytocin or peripheral apomorphine are antagonized in a dose-dependent manner by icv pretreatment with an oxytocin antagonist (12). These observations suggest that dopamine facilitates oxytocin release in male rats and that oxytocin may mediate these behaviors in rodents.

Although little is known regarding the roles of oxytocin and dopamine in sexual behavior in primates, recent studies have demonstrated that, similar to rats, apomorphine facilitates male sexual behavior in rhesus monkeys (13) and penile erections in normal and impotent men $(14,15)$. Whether these behavioral effects of apomorphine in primates are mediated through oxytocin release is unknown. Therefore, in the present study we administered dopamine receptor agonists to male and female monkeys and monitored both the oxytocin secretory responses in peripheral blood and behavior in order to correlate neuroendocrine and behavioral responses to these agents.

\section{Materials and Methods}

\section{Animals}

The animals used for this study were five adult female rhesus (no. 1319, 1479, 1807, 1863, and 2032), two adult male rhesus (no. 1851 
and 1957), and two adult male cynomolgus monkeys (no. 2051 and 2077). The female monkeys did not have regular menstrual cycles, but, rather, showed intermittent menstrual bleeding; therefore, the experiments in these animals were performed without regard to the stage of the menstrual cycle. The studies were conducted at the Primate Research Laboratory of the Center for Research in Reproductive Physiology at the University of Pittsburgh. The monkeys were housed individually in a temperature-controlled room $(24 \pm 2 \mathrm{C})$ in which the lights were on between $0700-1900 \mathrm{~h}$. The animals were fed daily at $1100 \mathrm{~h}$ a standard diet of monkey chow supplemented with fresh fruits. Water was given to the animals ad libitum.

At least 2 weeks before initiation of the studies, each monkey had a chronic indwelling Silastic catheter placed into either a femoral or jugular vein using sterile surgical techniques. The other end of the catheter was exteriorized through a cutaneous incision at the midscapular region of the back, and the catheter was run through a flexible metal tether to attach to a swivel (Alice King Chatham, Inc., Los Angeles, CA) mounted on top of the monkey's cage. Silastic tubing extended from the top of the swivel, through a hole in the wall, to an adjacent room to allow remote collection of blood samples. The catheter was kept patent with a continuous infusion of heparinized $(2.5 \mathrm{IU} / \mathrm{mL}) 0.9 \%$ saline at a rate of approximately $100 \mathrm{~mL} /$ day. The animals were fitted with jackets to prevent their access to the catheter (16).

\section{Experimental protocol}

Each monkey was studied on multiple occasions to test the neuroendocrine and behavioral responses to various doses of several dopamine agonists. On the day of each experiment, the following drugs, or the vehicle used to solubilize the drug, were administered iv at $0900 \mathrm{~h}$ using a randomized schedule, with $72 \mathrm{~h}$ or more intervening between the test paradigms: apomorphine (Research Biomedicals, Inc., Natick, MA; 50, 100,200 , and $400 \mu \mathrm{g} / \mathrm{kg}$ ); (-)-10,11-methylenedioxy- $N$-A-propylnoraporphine (MDO-NPA), a long-acting apomorphine derivative (17) (Research Biochemicals; 200, 400, and $800 \mu \mathrm{g} / \mathrm{kg}$ ); LY 163502, a dopamine $\mathrm{D}_{2}$ receptor agonist (Eli Lilly Co., Indianapolis, IN; $10,25,50$, and 100 $\mu \mathrm{g} / \mathrm{kg}$ ); and CY 208 243, a dopamine $D_{1}$ receptor agonist (Sandoz Pharmaceuticals, Basel, Switzerland; $100-400 \mu \mathrm{g} / \mathrm{kg}$ ). Apomorphine and MDO-NPA were solubilized in 10\% dimethylsulfoxide, CY-208-248 was solubilized in $0.1 \mathrm{M}$ tartaric acid, and LY 163502 was solubilized in saline. Two blood samples were collected at 5 -min intervals $(-10$ and $-5 \mathrm{~min}$ ) before administration of the drug, and one blood sample was drawn immediately after drug infusion $( \pm 2 \mathrm{~min})$. Blood samples were then drawn at 10-min intervals for the first hour and at 30-min intervals for the second hour after drug administration. Blood was collected into sterile heparinized syringes, transferred to sterile tubes, and then centrifuged at $3000 \times g$ for $15 \mathrm{~min}$. The plasma was separated from the red blood cells and stored at $-20 \mathrm{C}$ until assay. Red blood cells were resuspended in $0.9 \%$ saline and reinfused into the animals. Oxytocin was measured in plasma after acetone-ether extraction, using an antibody specific for intact oxytocin $(1820)$. The inter and intraassay coefficients of variation for the oxytocin assays were $10 \%$.

During the experiments, the behavior of the animals was assessed by conducting a series of 5 -min observations. Behavioral observations were initiated $5 \mathrm{~min}$ before drug treatment, continued immediately after treatment, and repeated at 10 -min intervais thereafter. Behaviors that were scored included episodes of yawning, signs of oral hyperkinesia (e.g. vacuous chewing, licking, and gnawing), and repetitive hypermobility (e.g. flipping, bobbing, and turning). In males, the occurrence of penile erections was also noted.

\section{Data analysis}

The oxytocin secretory response was calculated as the area under the curve. Area under the blood oxytocin concentration-time curves in response to apomorphine and other dopamine receptor agonists was calculated using an approximate integration formula. Specifically, the trapezoidal rule was used (21), in which each segment of the curve (between each two adjacent time points) was connected by a straight line, allowing the curve to be divided into a series of trapezoids. Areas of each trapezoid were calculated and added together, and the baseline area was subtracted to give a final area under the curve value. A oneway analysis of variance with repeated measures was used to investigate between-group comparisons. A significant omnibus test was followed by Dunnett's test, comparing each level with vehicle group values.

\section{Results}

The administration of apomorphine increased plasma oxytocin concentrations in a dose-dependent fashion (Figs. 13 and Table 1). The pattern of the oxytocin secretory response to increasing doses of apomorphine is shown for one female rhesus monkey (no. 1319; Fig. 1) and one male cynomolgus monkey (no. 2077; Fig. 2). In most animals, after apomorphine administration ( 200 and $400 \mu \mathrm{g} / \mathrm{kg}$ ), plasma oxytocin concentrations increased within minutes of injection of apomorphine and remained elevated above predrug levels for 30-60 min. However, the magnitude of the oxytocin secretory response was quite variable among the animals, so that a statistically significant $(P \leq 0.05)$ oxytocin response for the group was only apparent at the $400 \mu \mathrm{g} / \mathrm{kg}$ dose of apomorphine. Within a given monkey, the magnitude of the oxytocin secretory response was heightened, and the time period between apomorphine injection and peak oxytocin levels was decreased as the dose of apomorphine was increased (Figs. 1 and 2).

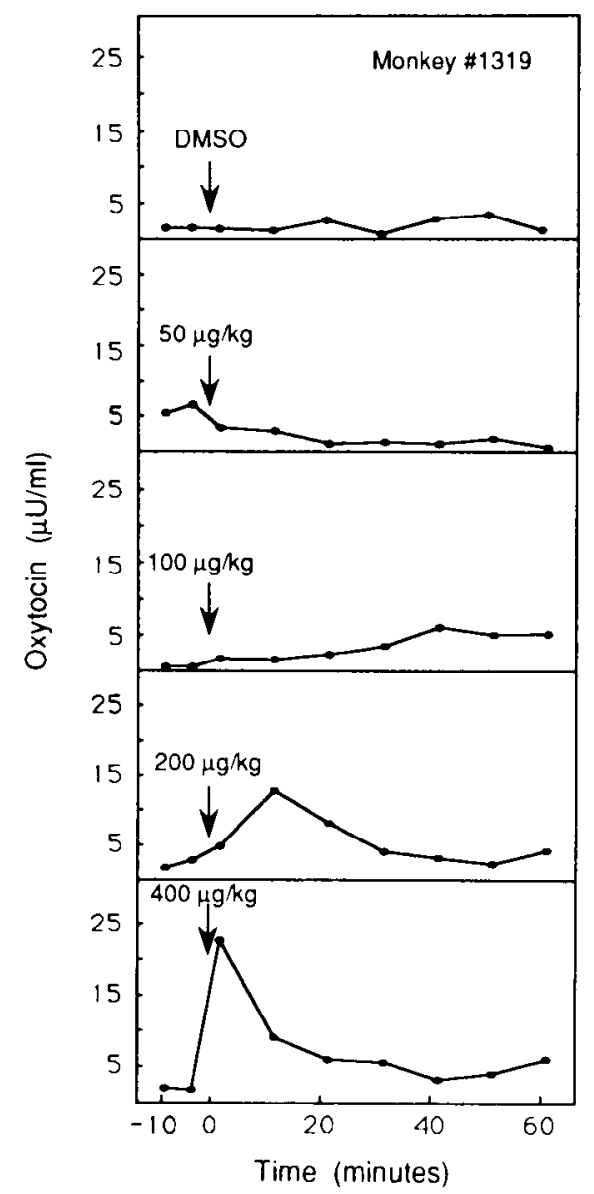

FIG. 1. Plasma oxytocin responses to increasing concentrations of apomorphine in a female rhesus monkey (no. 1319). The oxytocin response to vehicle [dimethylsulfoxide (DMSO)] administration is shown in the top panel. 


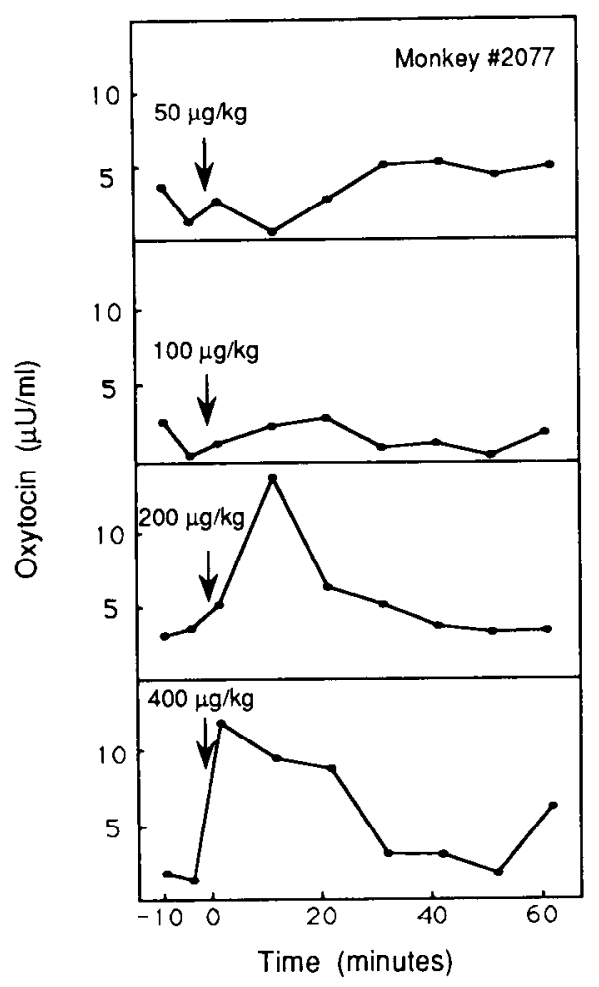

FIG. 2. Plasma oxytocin responses to increasing concentrations of apomorphine in an adult male cynomolgus monkey (no. 2077).

MDO-NPA, a long-acting derivative of apomorphine, also induced an increase in the plasma oxytocin secretory response in the animals $(200,400$, and $800 \mu \mathrm{g} / \mathrm{kg})$. The pattern of the oxytocin secretory response induced by MDO-NPA was similar to that induced by apomorphine (data not shown).

We also tested the effect of administering iv the respective dopamine $D_{1}$ and $D_{2}$ receptor agonists, CY 208-243 and LY 163502 , on the oxytocin secretory response in these animals. The dopamine $D_{2}$ receptor agonist LY $163502(10-100 \mu \mathrm{g} /$ $\mathrm{kg}$ ) elicited a dose-dependent increase in plasma oxytocin concentrations (Fig. 4 and Table 1). Although, again because of variable oxytocin responses among animals, only the 50 $\mu \mathrm{g} / \mathrm{kg}$ dose of LY 163502 caused a statistically significant $(P$ $<0.05$ ) increase in the mean oxytocin release for the group. However, the overall pattern of the oxytocin secretory response to this dopamine $D_{2}$ agonist was similar to that observed with apomorphine. In contrast, CY 208-243 (100$400 \mu \mathrm{g} / \mathrm{kg}$ ) increased plasma oxytocin concentrations only at the $400 \mu \mathrm{g} / \mathrm{kg}$ dose (to a mean level of $122 \pm 54 \mu \mathrm{U} / \mathrm{h} \cdot \mathrm{mL}$ ), and this effect failed to reach statistical significance. There was no apparent stimulation in any of the monkeys at lower doses of CY 208-243.

We correlated the behavioral observations in these animals with the oxytocin secretory responses to graded doses of apomorphine, CY 208-243, and LY 163502. No behavioral effects of CY $208-243(100-400 \mu \mathrm{g} / \mathrm{kg})$ were observed. Apomorphine and LY 163502 both induced repeated episodes of yawning or oral dyskinesia coupled with hypermobility. The behaviors had their onset immediately after the injection of the drug and persisted throughout the first 15-20 min of the 60 -min observation period. The percentage of animals displaying yawning (shown in the top panel of Fig. 3) was greatest with the lower doses of apomorphine (50-100 $\mu \mathrm{g} /$ $\mathrm{kg}$ ) and was not observed at the highest dose of apomorphine $(400 \mu \mathrm{g} / \mathrm{kg}$ ). In contrast, the percentage of animals exhibiting oral dyskinesia and hypermobility (shown in the middle panel of Fig. 3) increased as the dose of administered apomorphine increased and was observed infrequently at the lowest dose of apomorphine $(50 \mu \mathrm{g} / \mathrm{kg})$. Neither yawning nor oral dyskinesia was observed after the administration of vehicle.

Similar patterns of behavior were noted in response to the various doses of LY 163502. Low doses of LY 163502 (10$25 \mu \mathrm{g} / \mathrm{kg}$ ) elicited the highest levels of yawning, and high doses $(50-100 \mu \mathrm{g} / \mathrm{kg})$ elicited stereotypy in $100 \%$ of the monkeys (Fig. 4). At lower doses of apomorphine and LY 163502 , no significant increases in plasma oxytocin concentrations were associated with yawning (Figs. 3 and 4). However, at higher doses of apomorphine and LY 163502, increases in plasma oxytocin concentrations were associated with oral dyskinesia and hypermobility (Figs. 3 and 4). Penile erections were observed in one, two, one, and zero of the four male monkeys administered 50,100, 200, and $400 \mu \mathrm{g} /$ $\mathrm{kg}$ apomorphine, respectively. One of the four male monkeys exhibited penile erections after $10 \mu \mathrm{g} / \mathrm{kg}$ LY 163502 . Emetic responses were not observed in any of the animals during any of the studies.

\section{Discussion}

The results of this study in monkeys are in partial agreement with those of previous studies performed in rats. We

TABLE 1. Oxytocin secretory response to dopaminergic agonists

\begin{tabular}{|c|c|c|c|c|c|}
\hline & \multicolumn{5}{|c|}{ Dose of apomorphine $(\mu \mathrm{g} / \mathrm{kg})$} \\
\hline & Vehicle & 50 & 100 & 200 & 400 \\
\hline \multirow{4}{*}{$\begin{array}{l}\text { No. of animals } \\
\text { Mean } \pm \text { SE }\end{array}$} & 9 & 6 & 9 & 9 & 8 \\
\hline & $27.2 \pm 17$ & $44.3 \pm 34$ & $66.2 \pm 24$ & $106.2 \pm 33$ & $157 \pm 44$ \\
\hline & \multicolumn{5}{|c|}{ Dose of LY $163502(\mu \mathrm{g} / \mathrm{kg})$} \\
\hline & Vehicle & 10 & 25 & 50 & 10 \\
\hline $\begin{array}{l}\text { No. of animals } \\
\text { Mean } \pm \text { SE }\end{array}$ & $\begin{array}{c}9 \\
27.2 \pm 17\end{array}$ & $\begin{array}{c}7 \\
44 \pm 17\end{array}$ & $\begin{array}{c}4 \\
38 \pm 32\end{array}$ & $\begin{array}{c}9 \\
86 \pm 33\end{array}$ & $\begin{array}{c}4 \\
186 \pm 96\end{array}$ \\
\hline
\end{tabular}

\footnotetext{
Values are microunits of oxytocin per $\mathrm{h} / \mathrm{mL}$.
} 


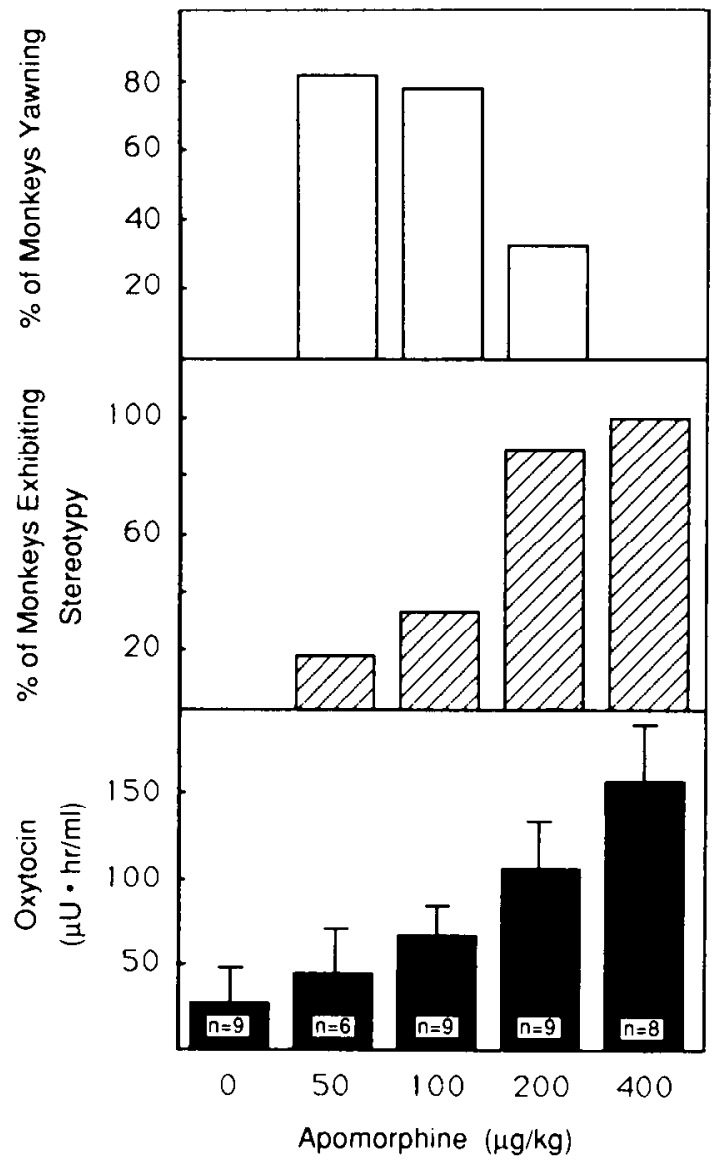

FIG. 3. Effects of increasing concentrations of apomorphine on the percentage of monkeys displaying yawning (top panel), the percentage of monkeys showing stereotypic behaviors (middle panel), and plasma oxytocin secretion (bottom panel; reported as total release over the first hour after the apomorphine injection). The number of monkeys studied at each dose is indicated in the insets in the bottom panel bars.

found that the dopaminergic receptor agonist apomorphine increased the concentration of oxytocin in the peripheral circulation of monkeys, as it did in rodents, in a dosedependent fashion (10). In rats, no significant oxytocin secretory response was seen with an apomorphine dose of 80 $\mu \mathrm{g} / \mathrm{kg}(10)$. In monkeys, increases in oxytocin were not found at low doses $(e .8 .50 \mu \mathrm{g} / \mathrm{kg})$, but were elicited as the dose was increased. The oxytocin secretory response to apomorphine was observed in female rhesus monkeys as well as in male rhesus and cynomolgus monkeys, indicating that the response is not sex related or species specific. The oxytocin secretory response was quite variable among the animals, with some monkeys displaying marked increases, and others displaying minimal increases in plasma oxytocin concentrations. The cause of the variable oxytocin response to apomorphine among the different animals used in this study is not known. However, a similar variability in behavioral responses to apomorphine was found (as discussed below). Interestingly, within given monkeys there was a strong correlation between the oxytocin and behavioral responses to apomorphine, so that monkeys who showed the most dramatic oxytocin secretory responses to the high doses of

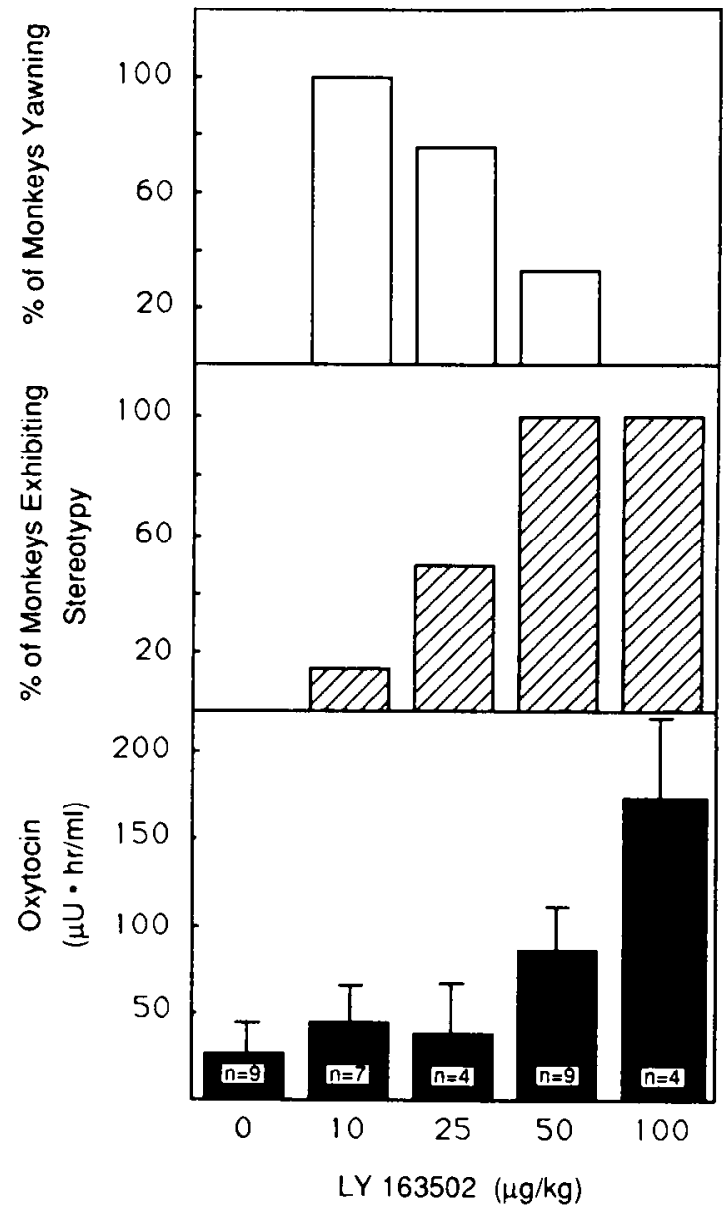

FIG. 4. Effects of increasing concentrations of LY 163502. See Fig. 3 for details.

apomorphine (e.g. 200 and $400 \mu \mathrm{g} / \mathrm{kg}$ ) also showed the greatest amount of stereotypic behavior and hypermobility at these doses. This finding suggests that these responses to dopamine stimulation may be linked to each other and that a threshold for responsiveness may exist that is variable among animals. Alternatively, the oxytocin and behavioral responses to apomorphine may be unrelated to each other, and the variable responses among animals may result from differences in factors such as dopamine receptor distribution or availability.

Since the effects of apomorphine on the release of neurohypophysial hormones in rodents are believed to be mediated by the dopamine $D_{2}$ receptor $(10-12)$, we administered dopamine $D_{1}$ and $D_{2}$ receptor agonists to the monkeys to evaluate whether one or both of these dopamine receptor subtypes were responsible for regulating oxytocin activity. A dose-related release of oxytocin was found with the dopamine $D_{2}$ receptor agonist LY 163502, whereas only a nonsignificant increased trend in plasma oxytocin concentrations was found with the highest dose $(400 \mu \mathrm{g} / \mathrm{kg})$ of CY 208 243. This trend toward an increase in oxytocin concentrations by the dopamine $D_{1}$ receptor agonist CY 208-243 at a dose of $400 \mu \mathrm{g} / \mathrm{kg}$, but not at lower doses, may be explained by the moderate affinity of this particular agonist for dopamine $\mathrm{D}_{2}$ receptors (22). Importantly, CY 208-243 did not elicit any 
behavioral effects in these animals, whereas both apomorphine and the dopamine $D_{2}$ receptor agonist LY 163502 elicited dose-related stimulations of oxytocin coupled with dose-specific behavioral changes in monkeys. Thus, dopamine $D_{2}$ receptors, as opposed to $D_{1}$ receptors, may be primarily responsible for regulating oxytocin secretion in primates.

In rodents, there is abundant evidence that apomorphine induces penile erection and yawning by releasing oxytocin into the central nervous system $(11,12)$. In rodents low doses of apomorphine ( 40 and $80 \mu \mathrm{g} / \mathrm{kg}$ ) elicit yawning and penile erections, whereas doses of apomorphine of $100 \mu \mathrm{g} / \mathrm{kg}$ or more cause hypermobility and stereotypy (10). In monkeys, although low doses of apomorphine (50-100 $\mu \mathrm{g} / \mathrm{kg}$ ) elicited yawning in the male and female monkeys that were studied and penile erections in two of the four male monkeys administered $100 \mu \mathrm{g} / \mathrm{kg}$ apomorphine, only a modest increase in oxytocin secretion was observed. In contrast, whereas yawning and penile erections were rarely observed at 100 $\mu \mathrm{g} / \mathrm{kg}$ apomorphine, these doses produced a substantial release of oxytocin as well as oral dyskinesia and stereotypy in all monkeys that we studied. Thus, it seems unlikely that in macaques, oxytocin mediates the behaviors of yawning and penile erections that are elicited by apomorphine administration. Of course, however, final proof of this conclusion will only be determined in experiments examining the behavioral responses to apomorphine in the presence of an oxytocin antagonist or antiserum.

To the best of our knowledge, dopamine's influence on plasma oxytocin concentrations has not been previously tested in monkeys. Apomorphine has been reported to increase the circulating concentrations of the closely related neurohypophysial peptide arginine vasopressin (AVP) in humans (23-27). The stimulus for apomorphine release of AVP in humans was found to be independent of volume or osmolar stimuli and thought to be mediated by the induction of nausea (23-27), because pretreatment of humans with an antiemetic agent typically abolishes the apomorphine-induced release of AVP (23). The doses of apomorphine used to induce nausea in humans ranged from $5-50 \mu \mathrm{g} / \mathrm{kg}$ BW and have produced a brisk AVP release without an associated release of oxytocin (25) or with minimal but statistically significant increases in plasma oxytocin (24). In addition, prior reports by Verbalis and co-workers (28) have indicated that other nauseogenic agents, such as lithium chloride, copper sulfate, or cholecystokinin, selectively increase AVP, but not oxytocin, concentrations in nonhuman primates. Based upon these observations, Verbalis and co-workers (28) have suggested that there is a specific neurohypophysial hormone secretion in response to nauseogenic agents involving the release of AVP, but not oxytocin, in primates.

In contrast to the studies with humans, our findings indicate that high doses of apomorphine $(>50 \mu \mathrm{g} / \mathrm{kg})$ can elicit both AVP and oxytocin release in primates, as shown by our recent finding that the same high doses of apomorphine (e.g. $50-400 \mu \mathrm{g} / \mathrm{kg}$ ) used in the present study also elicit AVP release in monkeys (29). Oxytocin release in monkeys with high doses of apomorphine may or may not be induced by nausea. Surprisingly, the doses of apomorphine used in the present study did not elicit emetic behavior in any of the monkeys, although these were higher doses of apomorphine than those that induced nausea and emesis in humans (25). However, although no monkeys in this study displayed emetic behavior, we have no way of knowing if they were feeling nauseated. It is also possible that apomorphine is less of a nauseogenic agent in monkeys than in humans and that the responses of oxytocin and AVP to apomorphine that we found in monkeys are independent of nausea. Further studies in which monkeys are pretreated with an antiemetic agent could potentially help resolve this issue.

An important finding from this study is that dopamine receptor agonists release oxytocin into the plasma of primates. Few stimuli are known to release oxytocin into primate plasma. Of these, suckling is the most reproducible physiological stimulus for oxytocin release (1). However, no pharmacological stimulus for oxytocin release has previously been identified in primates, although a few pharmacological agents are known to release oxytocin in rodents (i.e. cholecystokinin and apomorphine) $(10,28)$. The lack of a pharmacological stimulus to elicit oxytocin secretion in primates has made study of this peptide in primate species difficult. By identifying dopaminergic agonists, and in particular $\mathrm{D}_{2}$ receptor agonists, as potent inducers of oxytocin release in monkeys, these agonists may become useful pharmacological tools for further studies exploring the physiological actions of oxytocin in primates as well as for studies examining the pharmacological systems influencing oxytocinergic neurons in primates.

\section{Acknowledgments}

The authors gratefully acknowledge the following individuals: Janine Janosky, Ph.D., for statistical analysis of the data; Ms. Dawn Murphy, Mrs. Ludka Stolc, and Mrs. Darina Sipula for technical assistance; and Mrs. Marge Altvater and Mrs. Michele Dobransky for secretarial assistance. We thank Sandoz Pharmaceuticals and Eli Lilly Co. for the generous gifts of CY 208-243 and LY 163502, respectively.

\section{References}

1. Robinson ICAF, 1986 Oxytocin and the milk-ejection reflex. In: Ganten D, Pfaff D, eds. Current topics in neuroendocrinology. Berlin: Springer-Verlag; vol 6:153-72.

2. Fuchs AR. 1985 Oxytocin in animal parturition. In: Amico JA, Robinson AG, eds. Oxytocin: clinical and laboratory studies. Amsterdam: Elsevier; pp 207-35

3. Mitchell MD, Haynes PJ, Anderson ABM, Turnbull AC. 1980 Oxytocin in human ovulation. Lancet. 2:704.

4. Carmichael MS, Humbert R, Dixen J, Palmisano G, Greenleaf $W$, Davidson JM. 1987 Plasma oxytocin increases in the human sexual response. J Clin Endocrinol Metab. 64:27-31.

5. Pedersen CA, Ascher JA, Monroe KL, Prange Jr AJ, 1982 Oxytocin induces maternal behavior in virgin female rats. Science. 216: 648-9.

6. Caldwell JD, Prange Jr AJ, Pedersen CA. 1986 Oxytocin facilitates the sexual receptivity of estrogen-treated female rats. Neuropeptides. 7:175-89.

7. Arletti R, Bazzani C, Castelli M, Bertolini A. 1985 Oxytocin improves male copulatory performance in rats. Horm Behav. 19: $14-20$.

8. Andersen PH, Nielsen EB. 1986 The dopamine $D_{1}$ receptor: bio- 
chemical and behavioral aspects. In: Breese GR, Creese I, eds. Neurobiology of central $D_{1}$-dopamine receptors. New York, London: Plenum Press; pp 73-92.

9. Iorio LC, Barnett A, Billard W, Gold EH. 1986 Benzazepine: structure-activity relationships between $D_{1}$ receptor blockade and selected pharmacological effects. In: Breese CR, Creese I, eds. Neurobiology of central $D_{1}$-dopamine receptors. New York, London: Plenum Press; pp 1-14.

10. Melis MR, Argiolis A, Gessa GL. 1989 Apomorphine increases plasma oxytocin concentrations in male rats. Neurosci Lett. 98: 351-5.

11. Melis MR, Argiolas A, Gessa GL. 1989 Evidence that apomorphine induces penile erection and yawning by releasing oxytocin in the central nervous system. Eur J Pharmacol. 164:565-70.

12. Argiolas A, Collu M, D'Aquila P, Gessa GL, Melis MR, Serra G. 1989 Apomorphine stimulation of male copulatory behavior is prevented by the oxytocin antagonist $d\left(\mathrm{CH}_{2}\right)_{5} \mathrm{Tyr}(\mathrm{Me})-\mathrm{Orn}{ }^{8}$ vasotocin in rats. Pharm Biochem Behav. 33:81-3.

13. Pomerantz SM. 1990 Apomorphine facilitates male sexual behavior of rhesus monkeys. Pharm Biochem Behav. 35:659-64.

14. Lal S, Ackman D, Thavundayil JX, Kiely ME, Etienne P. 1984 Effect of apomorphine, a dopamine receptor agonist, on penile tumescence in normal subjects. Prog Neuropsychopharmacol Biol Psychiatry. 8:695-9.

15. Lal S, Laryea E, Thavundayil JX, et al. 1987 Apomorphine-induced penile tumescence in impotent patients-preliminary findings. Prog Neuropsychopharmacol Biol Psychiatry. 11:235-42.

16. Amico JA, Levin SC, Cameron JL. 1989 Circadian rhythm of oxytocin in the cerebrospinal fluid of rhesus and cynomolgus monkeys: effects of castration and adrenalectomy and presence of a caudal-rostral gradient. Neuroendocrinology. 50:624-32.

17. Baldessarini RJ, Neumyer JL, Campbell A, et al. 1982 An orally effective, long-acting dopaminergic prodrug: (-)-10,11-methylenedioxy- $N$-propylnoraporphine. Eur J Pharmacol. 77:87-8.

18. Amico JA, Seif SM, Robinson AG. 1981 Oxytocin in human plasma: correlation with neurophysin and stimulation with estrogen. J Clin Endocrinol Metab. 52:988-93.
19. Amico JA, Ervin MG, Leake RD, Fisher DA, Finn FM, Robinson AG. 1985 A novel oxytocin-like and vasotocin-like peptide in human plasma after administration of estrogen. J Clin Endocrinol Metab. 60:5-12.

20. Johnston JM, Amico JA. 1986 A prospective longitudinal study of the release of oxytocin and prolactin in response to infant suckling in long-term lactation. J Clin Endocrinol Metab. 62:653-7.

21. Garibaldi M, Perrier D, eds. 1982 Pharmacokinetics. New York: Marcel Dekker; $\mathrm{p} 445$.

22. Markstein R, Seiler MP, Vigouret JM, Vruyler S, Enz A, Dixon K. 1987 Pharmacologic properties of CY208-243, a novel $D_{1}$ agonist. In: Progress in catecholamine research, part B. New York: Liss; pp 59-64.

23. Rowe JW, Shelton RL, Helderman JH, Vestal RE, Robertson GL 1979 Influence of the emetic reflex on vasopressin release in man. Kidney Int. 16:729-35.

24. Nussey SS, Hawthorn J, Page SR, Ang VTY, Jenkins JS. 1988 Responses of plasma oxytocin and arginine vasopressin to nausea induced by apomorphine and ipecacuanha. Clin Endocrinol (Oxf). 28:297-304.

25. Feldman M, Samson WK, O'Dorisio TM. 1988 Apomorphineinduced nausea in humans: release of vasopressin and pancreatic polypeptide. Gastroenterology. 95:721-6.

26. Sorenson PS, Hammer M. 1985 Vasopressin in plasma and ventricular cerebrospinal fluid during dehydration, postural changes, and nausea. Am J Physiol, 248:R78-83.

27. Fisher RD, Rentschler RE, Nelson JC, Godfrey TE, Wilbur DW. 1982 Elevation of plasma antidiuretic hormone (ADH) associated with chemotherapy-induced emesis in man. Cancer Treat Rep. 66:25-9.

28. Verbalis JG, Richardson DW, Stricker EM. 1987 Vasopressin release in response to nausea-producing agents and cholecystokinin in monkeys. Am J Physiol. 252:R749-53.

29. Amico JA, Pomerantz SM, Layden LM, Cameron JL. Effects of dopamine receptor agonists upon oxytocin and vasopressin secretion in monkeys. Proc of the 21st Annual Meet of the Soc for Neurosci. 1991; p 588.5. 